\title{
Vulcanibacillus modesticaldus gen. nov., sp. nov., a strictly anaerobic, nitrate-reducing bacterium from deep-sea hydrothermal vents
}

Correspondence

C. Jeanthon

jeanthon@sb-roscoff.fr
S. L'Haridon, ${ }^{1}$ M. L. Miroshnichenko, ${ }^{2}$ N. A. Kostrikina, ${ }^{2}$ B. J. Tindall, ${ }^{3}$ S. Spring, ${ }^{3}$ P. Schumann, ${ }^{3}$ E. Stackebrandt, ${ }^{3}$ E. A. Bonch-Osmolovskaya ${ }^{2}$ and C. Jeanthon ${ }^{1} \dagger$

\author{
${ }^{1}$ UMR 6197, Centre National de la Recherche Scientifique, IFREMER and Université de \\ Bretagne Occidentale, Institut Universitaire Européen de la Mer, 29280 Plouzané, France \\ ${ }^{2}$ Institute of Microbiology, Russian Academy of Sciences, Prospect 60-letiya Oktyabraya 7/2, \\ 117811 Moscow, Russia \\ ${ }^{3}$ German Collection of Microorganisms and Cell Cultures (DSMZ), Mascheroder Weg $1 \mathrm{~b}$, \\ 38124 Braunschweig, Germany
}

Deep-sea hydrothermal vents encompass diverse microbial habitats inhabited by unique microbial communities. Traditional culture-based approaches have led to the characterization of numerous microbes that include mesophiles, thermophiles and hyperthermophiles from diverse trophic groups (Jeanthon, 2000). Of the thermal classes isolated from deep-sea vents, less attention has been paid to mesophiles and moderate thermophiles in comparison with hyperthermophiles. In particular, mesophilic and moderately thermophilic micro-organisms belonging to the Epsilonproteobacteria, a prevalent group in culture-independent molecular analyses, have only recently been obtained in culture (Miroshnichenko et al., 2002, 2004; Takai et al., 2003).

tPresent address: UMR 7144, Equipe Phytoplancton Océanique, Station Biologique, Place Georges-Teissier, 29680 Roscoff Cedex, France.

The GenBank/EMBL/DDBJ accession number for the 16S rRNA gene sequence of strain $\mathrm{BR}^{\top}$ is $\mathrm{AM} 050346$.

Electron micrographs and details of the polar lipid and cellular fatty acid compositions of strain $\mathrm{BR}^{\top}$ are available as supplementary material in IJSEM Online.
Of the thermophiles isolated from these environments, only a few belong to the Gram-positive bacteria. To date, thermophilic Gram-positive isolates from deep-sea hydrothermal vents comprise aerobic bacilli (Marteinsson et al., 1996) and strict anaerobes of the orders 'Thermoanaerobacteriales' (Sokolova et al., 2001; Fardeau et al., 2004) and Clostridiales. The latter include recently described species of the genera Caloranaerobacter (Wery et al., 2001), Clostridium (Brisbarre et al., 2003) and Tepidibacter (Slobodkin et al., 2003; Urios et al., 2004).

In this paper, we describe a strictly anaerobic, moderately thermophilic, Gram-positive, spore-forming bacterium that was isolated from a deep-sea hydrothermal vent sediment sample; this novel organism has phenotypic, chemotaxonomic and phylogenetic characteristics that allow its assignment to a novel genus within the family Bacillaceae.

Chimney and core samples were collected at the Rainbow hydrothermal vent field on the Mid-Atlantic Ridge $\left(36^{\circ} 16^{\prime}\right.$ $\mathrm{N} 33^{\circ} 54^{\prime} \mathrm{W} ; 2300 \mathrm{~m}$ depth) by the remotely operated vehicle Victor during the Iris Cruise. A brief description of 
the hydrothermal site and the sampling procedures has been reported elsewhere (Nercessian et al., 2005). Once on board, the samples were aseptically transferred in $50 \mathrm{ml}$ glass vials under $\mathrm{N}_{2}$. The vials were closed tightly with butyl rubber stoppers (Bellco), pressurized with $\mathrm{N}_{2}(100 \mathrm{KPa})$, reduced with sodium sulfide, if required, and stored at $4{ }^{\circ} \mathrm{C}$ until needed.

The enrichment medium (EM) contained the following ( $\mathrm{g} \mathrm{l}^{-1}$ unless indicated otherwise): $\mathrm{NH}_{4} \mathrm{Cl}, 0 \cdot 33 ; \mathrm{KCl}, 0 \cdot 33$; $\mathrm{KH}_{2} \mathrm{PO}_{4}, 0 \cdot 33 ; \mathrm{CaCl}_{2} .2 \mathrm{H}_{2} \mathrm{O}, 0.33 ; \mathrm{MgCl}_{2} .6 \mathrm{H}_{2} \mathrm{O}, 0 \cdot 33 ; \mathrm{NaCl}$, $25 \cdot 0 ; \mathrm{NaNO}_{3}, 3 \cdot 0$, sodium acetate, $2 \cdot 0$; yeast extract, $0 \cdot 1$; trace element solution (Balch et al., 1979), $10 \mathrm{ml} \mathrm{l}^{-1}$; vitamin solution (Wolin et al., 1963), $10 \mathrm{ml} \mathrm{l}^{-1}$. The medium was prepared anaerobically (Balch et al., 1979) and dispensed in $15 \mathrm{ml}$ Hungate tubes; the headspace $(5 \mathrm{ml})$ was filled with $\mathrm{N}_{2}$ (atmospheric pressure). No reducing agents were added to the medium. The $\mathrm{pH}$ of the medium was $6 \cdot 5$. Single colonies were isolated using EM in which acetate had been replaced by tryptone $\left(2 \mathrm{~g} \mathrm{l}^{-1}\right)$ and which had been solidified with $1.5 \%$ agar (Difco), using a serial 10 -fold dilution technique in agar shake tubes. During routine cultivation of strain $\mathrm{BR}^{\mathrm{T}}$ in the laboratory, it was shown that the addition of $\mathrm{FeSO}_{4} .7 \mathrm{H}_{2} \mathrm{O}\left(0 \cdot 1 \mathrm{~g} \mathrm{l}^{-1}\right)$ and yeast extract $\left(0 \cdot 5 \mathrm{~g} \mathrm{l}^{-1}\right)$ to the medium significantly improved the stability and reproducibility of cell growth. An Olympus BH-2 microscope equipped with an Olympus OM-2 camera was used routinely to observe and count the bacteria. Gram staining was carried out as described by Murray et al. (1994). Staining of intracellular inclusions was done with Sudan black B, according to the protocol of Murray et al. (1994), and with Nile blue A, as described by Spring et al. (2005). Cells of Malikia granosa DSM $15619^{\mathrm{T}}$ that accumulate polyhydroxyalkanoates served as the control. The ultrastructure of whole cells and thin-section preparations was studied using a model JEM-100 electron microscope. Cells were prepared as described previously (BonchOsmolovskaya et al., 1990).

The influence of $\mathrm{pH}$ on growth was assessed using $10 \mathrm{mM}$ acetate/acetic acid buffer, MES, PIPES, HEPES and Tris between $\mathrm{pH} 4$ and 8.5 and without buffer above $\mathrm{pH} 8 \cdot 5$. The $\mathrm{pH}$ of the medium was adjusted after sterilization of the medium. The effect of $\mathrm{NaCl}$ on growth was determined on the same medium containing increasing $\mathrm{NaCl}$ concentrations. The effects of $\mathrm{pH}$ and of $\mathrm{NaCl}$ concentrations were determined at the optimal temperature for growth. Physiological tests were performed in EM from which sodium acetate and sodium nitrate had been omitted. Proteinaceous potential growth substrates were added at a concentration of $1 \mathrm{~g} \mathrm{l}^{-1}$ to the EM medium without acetate; carbohydrates, sodium salts of organic acids and alcohols were tested at a concentration of $3 \mathrm{~g} \mathrm{l}^{-1}$. When molecular hydrogen served as substrate, the headspace $(10 \mathrm{ml})$ was filled with a $\mathrm{H}_{2} / \mathrm{CO}_{2}$ mixture $(4: 1, \mathrm{v} / \mathrm{v})$. Possible electron acceptors, such as elemental sulfur $\left(5 \mathrm{~g} \mathrm{l}^{-1}\right)$, thiosulfate $(10 \mathrm{mM})$, sulfate $(10 \mathrm{mM})$ and nitrite $(10 \mathrm{mM})$, were tested. The ability to reduce amorphous $\mathrm{Fe}(\mathrm{III})$ oxide
(90 $\mathrm{mM})$ or $\mathrm{Fe}(\mathrm{III})$ citrate $(20 \mathrm{mM})$ was tested as described previously (Slobodkin et al., 1999). The ability to grow aerobically was determined in $100 \mathrm{ml}$ flasks containing the same medium $(10 \mathrm{ml})$. To check for microaerophilic growth, air was added to the headspace $(10 \mathrm{ml})$ of tubes filled with EM $(5 \mathrm{ml})$ lacking sodium nitrate. The final oxygen concentration varied from 0.5 to $9 \%$.

Growth was determined by measuring changes in turbidity at $600 \mathrm{~nm}$ by inserting culture tubes directly in a Spectronic 20D spectrophotometer (Bioblock). All growth experiments were performed in duplicate. $\mathrm{NO}, \mathrm{N}_{2} \mathrm{O}$ and $\mathrm{N}_{2}$ were tested by GC with a Porapak-Q column at $70{ }^{\circ} \mathrm{C}$ and at flow rates of $4 \mathrm{ml} \mathrm{min}{ }^{-1}$ (the carrier gas was argon). For quantitative nitrite analysis, $0 \cdot 1 \mathrm{ml}$ culture medium was added to a mixture containing $0.9 \mathrm{ml}$ deionized water, $0.5 \mathrm{ml} 0.6 \%$ solution of sulfanilic acid in $20 \% \mathrm{HCl}$ and $0.5 \mathrm{ml}(60 \mathrm{mg}$ per $50 \mathrm{ml}$ ) solution of $N$-naphthylethylenediamine. The absorbance at $548 \mathrm{~nm}$ was measured after $15 \mathrm{~min}$ (the time necessary for colour development). For quantitative nitrate analysis, the method of Cataldo et al. (1975) was used. Oxidase activity was assayed using discs impregnated with dimethyl-p-phenylenediamine (bioMérieux). Catalase activity was assayed by mixing a pellet of fresh culture with a drop of $\mathrm{H}_{2} \mathrm{O}_{2}(10 \%$, v/v).

EM medium was inoculated with different samples collected at the Rainbow hydrothermal site. After incubation at $55^{\circ} \mathrm{C}$, long thin rods were observed in enrichments from one chimney sample and two core samples. The cultures were diluted and transferred into EM agar. After 5 days incubation at $60{ }^{\circ} \mathrm{C}$, single cream-coloured colonies about $2 \mathrm{~mm}$ in diameter were visible in the agar shake tubes. The pure culture obtained after regrowth in liquid EM medium was designated strain $\mathrm{BR}^{\mathrm{T}}$. Cells of strain $\mathrm{BR}^{\mathrm{T}}$ consisted of long thin rods, $4-5 \mu \mathrm{m}$ in length and $0 \cdot 2-0 \cdot 3 \mu \mathrm{m}$ in diameter (see Supplementary Fig. S1 in IJSEM Online). Cells generally occurred singly and stained Gram-positive. In the early phase of growth, inclusions of reserve polymers were frequently detected, and caused the cells to swell. The reserve compound was highly refractile under phase-contrast microscopy and stained black with the lipophilic stain Sudan black B. In contrast, the affinity for the stain Nile blue A, which is known to be highly specific for polyhydroxyalkanoates, was quite low, such that no red fluorescence could be detected by epifluorescence microscopy. Hence, we presume that the reserve compound might represent an unknown storage lipid. Flagella were not seen on negatively stained electron preparations, and no swimming motility was observed. Spore-forming cells could be observed in the early stage of propagation of the strain after its isolation. Cells lysed rapidly at the beginning of the stationary phase of growth. Colonies showed a negative reaction for oxidase and catalase.

Strain $\mathrm{BR}^{\mathrm{T}}$ grew at temperatures between 37 and $60^{\circ} \mathrm{C}$, with an optimum at $55^{\circ} \mathrm{C}$; no growth was observed at 30 or $65^{\circ} \mathrm{C}$. The $\mathrm{pH}$ range for growth was between 6 and $8 \cdot 5$, with an optimum at $\mathrm{pH} 7$; no growth was observed at 
$\mathrm{pH} 5.5$ or 9. Strain $\mathrm{BR}^{\mathrm{T}}$ grew with $\mathrm{NaCl}$ concentrations ranging from 10 to $40 \mathrm{~g} \mathrm{l}^{-1}$, with an optimum at 20$30 \mathrm{~g} \mathrm{l}^{-1}$; no growth was observed without $\mathrm{NaCl}$ or in the presence of $50 \mathrm{~g} \mathrm{NaCl}^{-1}$.

Strain $\mathrm{BR}^{\mathrm{T}}$ was strictly anaerobic: it was unable to grow under aerobic or microaerophilic conditions. Nitrate was essential for growth and was reduced to nitrite. Nitrate was not further reduced to ammonia or $\mathrm{N}_{2}$. Elemental sulfur, thiosulfate, sulfate, nitrite, amorphous $\mathrm{Fe}(\mathrm{III})$ oxide $(90 \mathrm{mM})$ and $\mathrm{Fe}(\mathrm{III})$ citrate $(20 \mathrm{mM})$ could not be used as alternative electron acceptors. The substrates used for growth in the presence of nitrate as electron acceptor were acetate, yeast extract, tryptone, Bio-Trypticase, Bactopeptone, sucrose, glucose, fructose, starch, cellobiose, ethanol and pyruvate. Malate, succinate, methanol, formate, lactate, galactose, arabinose, lactose, butyrate and propionate were not used. No fermentative growth was observed.

Cell-wall preparations were obtained by boiling cells in $10 \%$ $(\mathrm{w} / \mathrm{v})$ aqueous trichloroacetic acid solution for $20 \mathrm{~min}$, washing them with water and subsequently treating them with trypsin at $37^{\circ} \mathrm{C}$, as described by Schleifer \& Kandler (1972). Diaminopimelic acid isomers were detected in cell-wall hydrolysates $\left(4 \mathrm{M} \mathrm{HCl}, 100^{\circ} \mathrm{C}, 16 \mathrm{~h}\right)$ by TLC on cellulose sheets (Merck), using the solvent system of Rhuland et al. (1955).

Respiratory lipoquinones and polar lipids were extracted from $100 \mathrm{mg}$ freeze-dried cell material using the two-stage method described by Tindall (1990a, b). Fatty acids were analysed as the methyl ester derivatives prepared from $10 \mathrm{mg}$ dry cell material. Cells were subjected to differential hydrolysis in order to detect ester-linked and non-esterlinked (amide-bound) fatty acids (B. J. Tindall, unpublished). Fatty acid methyl esters were analysed by GC using a $0 \cdot 2 \mu \mathrm{m} \times 25 \mathrm{~m}$ non-polar capillary column and flameionization detection. The run conditions were as follows: injection and detector port temperature, $300^{\circ} \mathrm{C}$; inlet pressure, $60 \mathrm{kPa}$, split ratio, 50:1; injection volume, $1 \mu \mathrm{l}$; temperature program, $130-310^{\circ} \mathrm{C}$ at a rate of $4{ }^{\circ} \mathrm{C} \mathrm{min}{ }^{-1}$.

The peptidoglycan of strain $\mathrm{BR}^{\mathrm{T}}$ contained mesodiaminopimelic acid as the diagnostic diamino acid, which is consistent with the occurrence of peptidoglycan type A1 $\gamma$ according to Schleifer \& Kandler (1972). The predominant menaquinone was MK-7. The fatty acids comprised a mixture of straight-chain and branched (isoand anteiso-) fatty acids (see Supplementary Table S1); i-15:0 predominates among the fatty acids $(>69 \%)$, but ai-15:0, 16:0, i-17:0 $(4 \cdot 8-8 \cdot 1 \%)$ and $14: 0,15: 0$,

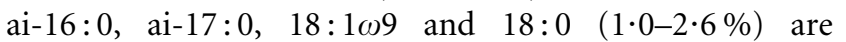
also present. The polar lipids comprised a comparatively simple pattern of phospholipids, including phospholipids and aminophospholipids. The major polar lipids comprised phosphatidylglycerol, diphosphatidylglycerol, phosphatidylethanolamine, two unidentified phospholipids and an unidentified aminophospholipid (see Supplementary Fig. S2).
The presence of predominantly iso- and/or anteiso-fatty acids, the absence of hydroxy fatty acids and the presence of menaquinones as the major respiratory quinones are features of organisms associated with 'Bacillus and relatives'. Although most of the members of this group produce MK-7, there is evidence that shorter (MK-6) or longer (MK-8 or MK-9) menaquinones may also predominate, providing a limited degree of differentiation within the group. With regard to the fatty acids, i-/ai-15:0 or i-/ai-17:0 usually predominate, although the relative proportions of the fatty acids, together with the presence/absence of other fatty acids, may indicate that there are larger groupings within the bacilli. The resolution of such data, however, are not usually sufficient to allow clear definition of groupings that might correlate with genera (Kämpfer, 1994, 2002). With regard to the polar lipids, the chemical diversity of various Bacillus species is well documented (Minnikin \& Minnikin, 1981; O'Leary \& Wilkinson, 1988), although there have been no serious attempts to use such data, together with physiological, morphological and genetic data, to define groupings within the bacilli that might be regarded as genera.

In describing a novel taxon that, through 16S rRNA gene sequence analysis, shows a degree of similarity to the type species of the genus Bacillus (Bacillus subtilis), it is important not only to develop a concept of what constitutes the novel genus, but also to consider how the genus Bacillus should be defined in the future. Although great emphasis has been placed on the use of 16S rRNA gene sequences (with the definition of RNA groups), this has still not led to a new definition of the genus Bacillus. Given the well-documented chemical diversity of various species previously or currently assigned to the genus Bacillus, it would appear opportune to consider the differences between the chemical composition of the type species of the genus (B. subtilis), as the nomenclatural type of the genus, and the new taxon. Although both strain $\mathrm{BR}^{\mathrm{T}}$ and $B$. subtilis DSM $10^{\mathrm{T}}$ share MK-7 and iso-/ anteiso-branched fatty acids, there are some differences in the fatty acid patterns (Supplementary Table S1), as well as in the polar lipid profiles. In particular, B. subtilis DSM $10^{\mathrm{T}}$ produces phosphatidylglycerol, diphosphatidylglycerol, phosphatidylethanolamine, a glycolipid and an aminophospholipid with an $R_{\mathrm{F}}$ value different from that found in strain $\mathrm{BR}^{\mathrm{T}}$ (Supplementary Fig. S2). The similarities between the two organisms are clearly indicative of the fact that they both belong to the bacilli, but the differences indicate that strain $\mathrm{BR}^{\mathrm{T}}$ should not be included in the genus Bacillus.

DNA was isolated after disruption of cells using a French pressure cell (Thermo Spectronic) and purified by hydroxyapatite chromatography (Cashion et al., 1977). The DNA was hydrolysed with P1 nuclease and the nucleotides were dephosphorylated with bovine alkaline phosphatase (Mesbah et al., 1989). The DNA G $+\mathrm{C}$ content was determined by using the HPLC method described by Tamaoka \& Komagata (1984).

Genomic DNA extraction, PCR-mediated amplification of the 16S rRNA gene and sequencing of PCR products were 
carried out as described by Rainey et al. (1996). The sequence reaction mixtures were electrophoresed using a model 373A automated DNA sequencer (Applied Biosystems).

The 16S rRNA gene sequence of strain $\mathrm{BR}^{\mathrm{T}}$ was aligned with published sequences obtained from the EMBL nucleotide sequence database and the Ribosomal Database Project using the ae2 editor (Maidak et al., 2001) and the ARB program (Ludwig et al., 2004). Evolutionary distance calculations were based on the algorithms of Jukes \& Cantor (1969), DeSoete (1983) and Felsenstein (1993), using neighbour-joining, maximum-likelihood and parsimony methods of tree reconstruction.

The $\mathrm{G}+\mathrm{C}$ content of the DNA of strain $\mathrm{BR}^{\mathrm{T}}$ was shown to be $34.5 \mathrm{~mol} \%$. The $16 \mathrm{~S}$ rRNA gene sequence of strain $\mathrm{BR}^{\mathrm{T}}$ had only similarity values below $93 \%$ with those of its closest relatives. Its phylogenetic position differed slightly according to the algorithm used and the selection of sequences included in the analysis. In no case, however, did strain $\mathrm{BR}^{\mathrm{T}}$ cluster specifically with one of the established taxa (Fig. 1).

Of the thermophilic, endospore-forming rods belonging to genera of the family Bacillaceae (Garrity et al., 2003), only a few are strict anaerobes. Bacillus infernus, Bacillus macyae and Bacillus arseniciselenatis are the only three strictly anaerobic representatives of the genus Bacillus (Boone et al., 1995; Switzer Blum et al., 1998; Santini et al., 2004). The species Bacillus selenitireducens and Anoxybacillus pushchinoensis are facultatively aerobic, but grow better under anaerobic conditions (Switzer Blum et al., 1998; Pikuta et al. 2000). Other significant phenotypic differences (e.g. in DNA $\mathrm{G}+\mathrm{C}$ contents, the presence of catalase and the cellular fatty acid composition) were found between these organisms (Table 1). Therefore, on the basis of physiological and genomic characteristics, fatty acid composition and $16 \mathrm{~S}$ rRNA gene sequence analysis, we propose the creation of a novel genus, Vulcanibacillus gen. nov., with Vulcanibacillus modesticaldus sp. nov. as the type species.

\section{Description of Vulcanibacillus gen. nov.}

Vulcanibacillus (Vul.ca.ni.ba.cil'lus. L. n. Vulcanus the Roman god of fire; L. dim. n. bacillus a small rod; N.L. masc. Vulcanibacillus a bacillus living in the vicinity of volcanic areas).

Cells are rod-shaped and produce spores. Cells occur mostly singly and are not motile. The cell-wall structure is Gram-positive. Moderately thermophilic, neutrophilic and adapted to the salinity of sea water. Strictly anaerobic. Chemo-organotrophic, using nitrate as the sole electron acceptor, this being reduced to nitrite. Nitrate is not further reduced to ammonia or $\mathrm{N}_{2}$. No fermentation occurs. Oxidase- and catalase-negative. Produces MK-7 as the major respiratory lipoquinone. The predominant fatty acid is $\mathrm{i}-15: 0$, but $14: 0$, ai- $15: 0,15: 0$, ai- $16: 0,16: 0, \mathrm{i}-17: 0$, ai-17:0, 18:1 109 and $18: 0$ are also present. The polar lipids comprise phosphatidylglycerol, diphosphatidylglycerol and phosphatidylethanolamine, as well two unidentified phospholipids (PL1 and PL2) and a single unidentified aminophospholipid. The DNA G + C content is $34 \cdot 5 \mathrm{~mol} \%$. $16 \mathrm{~S}$ rRNA gene sequence analysis places Vulcanibacillus in the class 'Bacilli'. The type species of the genus is Vulcanibacillus modesticaldus.

\section{Description of Vulcanibacillus modesticaldus sp. nov.}

Vulcanibacillus modesticaldus (mo.des'ti.cal.dus. L. adj. modestus moderate; L. adj. caldus warm, hot; N.L. masc. adj. modesticaldus moderately hot).

In addition to having the characteristics given in the genus description (above), cells are rods, $4-5 \mu \mathrm{m}$ in length and $0 \cdot 2-0 \cdot 3 \mu \mathrm{m}$ in diameter. Colonies of strain $\mathrm{BR}^{\mathrm{T}}$ are lensshaped and cream in colour. The temperature range for growth is $37-60^{\circ} \mathrm{C}$, with an optimum at $55^{\circ} \mathrm{C}$. Neutrophilic. The optimum $\mathrm{NaCl}$ concentration for growth is $2-3 \%$. Substrates used for growth in the presence of nitrate as electron acceptor include acetate, yeast extract, tryptone, Bio-Trypticase, Bacto-peptone, sucrose, glucose, fructose, starch, cellobiose, ethanol and pyruvate. Elemental sulfur, thiosulfate, sulfate, nitrite, amorphous $\mathrm{Fe}(\mathrm{III})$ oxide $(90 \mathrm{mM})$ and $\mathrm{Fe}(\mathrm{III})$ citrate $(20 \mathrm{mM})$ cannot be used as alternative electron acceptors. Malate, succinate, methanol, formate, lactate, galactose, arabinose, lactose, butyrate and

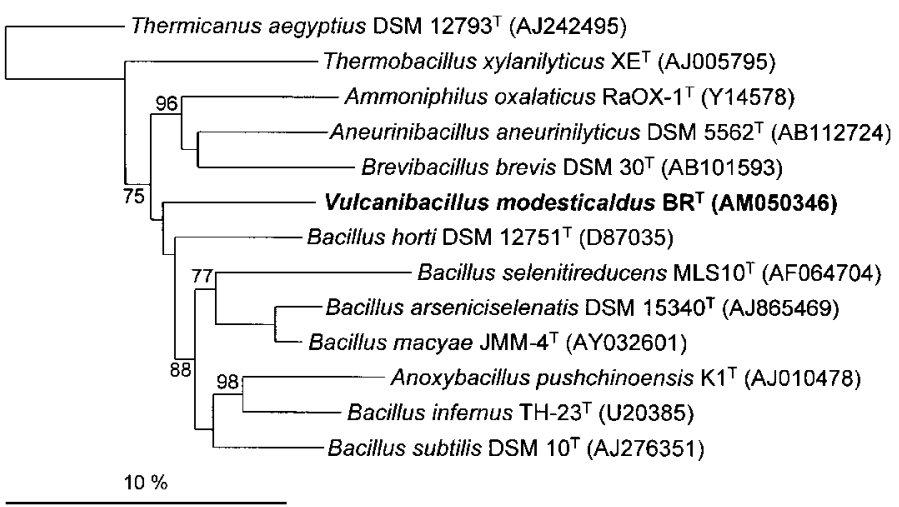

Fig. 1. Phylogenetic tree of strain $B R^{\top}$ and selected members of Bacillus and related taxa based on neighbour-joining analysis. Numbers (\%) at branch points are bootstrap values greater than $70 \%$. Bar, $10 \%$ sequence divergence. 


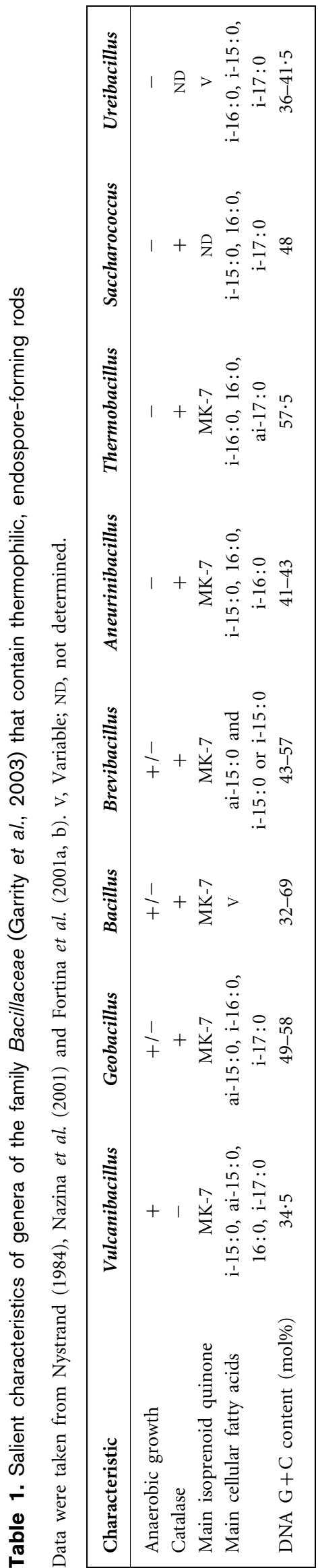

propionate are not used. The chemical composition of the species is identical to that given for the genus.

The type strain, $\mathrm{BR}^{\mathrm{T}}\left(=\mathrm{DSM} 14931^{\mathrm{T}}=\mathrm{JCM} 12998^{\mathrm{T}}\right)$, was isolated from a core sample collected at the Rainbow vent field on the Mid-Atlantic Ridge ( $\left.36^{\circ} 14^{\prime} \mathrm{N}\right)$.

\section{Acknowledgements}

We thank Yves Fouquet (Chief Scientist), for inviting us to participate in the Iris Cruise (2001), and the crews of R/V L'Atalante and pilots of ROV Victor. This work was supported by a PRIR (Conseil Régional de Bretagne) grant, a CNRS/Rhône-Poulenc grant, INTAS grant 99-1250, RFBR grant 00-04-4894, Programs 'Molecular and Cell Biology' and 'Origin and Evolution of the Biosphere' of the Russian Academy of Sciences and Program 'Biodiversity' of the Russian Ministry of Industry, Science and Technology. M. L. M. was supported by the Ministère de l'Education Nationale during her stay in France.

\section{References}

Balch, W. E., Fox, G. E., Magrum, G. E., Woese, G. E. \& Wolfe, R. S. (1979). Methanogens: reevaluation of a unique biological group. Microbiol Rev 43, 260-296.

Bonch-Osmolovskaya, E. A., Sokolova, T. G., Kostrikina, N. A. \& Zavarzin, G. A. (1990). Desulfurella acetivorans gen. nov. and sp. nov. - a new thermophilic sulfur-reducing eubacterium. Arch Microbiol 153, 151-155.

Boone, D. R., Liu, Y., Zhao, Z. J., Balkwill, D. L., Drake, G. R., Stevens, T. O. \& Aldrich, H. C. (1995). Bacillus infernus sp. nov., an $\mathrm{Fe}(\mathrm{III})$ - and $\mathrm{Mn}(\mathrm{IV})$-reducing anaerobe from the deep terrestrial subsurface. Int J Syst Bacteriol 45, 441-448.

Brisbarre, N., Fardeau, M.-L., Cueff, V. \& 7 other authors (2003). Clostridium caminithermale sp. nov., a slightly halophilic and moderately thermophilic bacterium isolated from an Atlantic deep-sea hydrothermal chimney. Int J Syst Evol Microbiol 53, 1043-1049.

Cashion, P., Holder-Franklin, M. A., McCully, J. \& Franklin, M. (1977). A rapid method for the base ratio determination of bacterial DNA. Anal Biochem 81, 461-466.

Cataldo, D. A., Haroon, M., Schrader, L. E. \& Youngs, V. L. (1975). Rapid colorimetric determination of nitrate in plant tissue by nitration of salicylic acid. Commun Soil Sci Plant Anal 6, 71-80.

DeSoete, G. (1983). A least squares algorithm for fitting additive trees to proximity data. Psychometrika 48, 621-626.

Fardeau, M.-L., Bonilla Salinas, M., L'Haridon, S., Jeanthon, C., Verhé, F., Cayol, J.-L., Patel, B. K. C., Garcia, J.-L. \& Ollivier, B. (2004). Isolation from oil reservoirs of novel thermophilic anaerobes phylogenetically related to Thermoanaerobacter subterraneus: reassignment of $T$. subterraneus, Thermoanaerobacter yonseiensis, Thermoanaerobacter tengcongensis and Carboxydibrachium pacificum to Caldanaerobacter subterraneus gen. nov., sp. nov., comb. nov. as four novel subspecies. Int J Syst Evol Microbiol 54, 467-474.

Felsenstein, J. (1993). PHYLIP (phylogeny inference package), version 3.5c. Distributed by the author. Department of Genome Sciences, University of Washington, Seattle, USA.

Fortina, M. G., Pukall, R., Schumann, P., Mora, D., Parini, C., Manachini, P. L. \& Stackebrandt, E. (2001a). Ureibacillus gen. nov., a new genus to accommodate Bacillus thermosphaericus (Andersson et al. 1995), emendation of Ureibacillus thermosphaericus and description of Ureibacillus terrenus sp. nov. Int J Syst Evol Microbiol 51, $447-455$. 
Fortina, M. G., Mora, D., Schumann, P., Parini, C., Manachini, P. L. \& Stackebrandt, E. (2001b). Reclassification of Saccharococcus caldoxylosilyticus as Geobacillus caldoxylosilyticus (Ahmad et al. 2000) comb. nov. Int J Syst Evol Microbiol 51, 2063-2071.

Garrity, G. M., Bell, J. A. \& Lilburn, T. G. (2003). Taxonomic outline of the prokaryotes. In Bergey's Manual of Systematic Bacteriology, release 4.0. http://141.150.157.80/bergeysoutline/main.htm

Jeanthon, C. (2000). Molecular ecology of hydrothermal vent microbial communities. Antonie van Leeuwenhoek 77, 117-133.

Jukes, T. H. \& Cantor, C. R. (1969). Evolution of protein molecules. In Mammalian Protein Metabolism, pp. 21-132. Edited by H. N. Munro. New York: Academic Press.

Kämpfer, P. (1994). Limits and possibilities of total fatty acid analysis for classification and identification of Bacillus species. Syst Appl Microbiol 17, 86-96.

Kämpfer, P. (2002). Whole-cell fatty acid analysis in the systematics of Bacillus and related genera. In Applications and Systematics of Bacillus and Relatives, pp. 271-299. Edited by R. Berkeley, M. Heyndrickx, N. Logan \& P. De Vos. Oxford: Blackwell.

Ludwig, W., Strunk, O., Westram, R. \& 29 other authors (2004). ARB: a software environment for sequence data. Nucleic Acids Res 32, 1363-1371.

Maidak, B. L., Cole, J. R., Lilburn, T. G. \& 7 other authors (2001). The RDP-II (Ribosomal Database Project). Nucleic Acids Res 29, 173-174.

Marteinsson, V. T., Birrien, J. L., Jeanthon, C. \& Prieur, D. (1996). Numerical taxonomic study of thermophilic Bacillus isolated from three geographically separated deep-sea hydrothermal vents. FEMS Microbiol Ecol 21, 255-266.

Mesbah, M., Premachandran, U. \& Whitman, W. B. (1989). Precise measurement of the $\mathrm{G}+\mathrm{C}$ content of deoxyribonucleic acid by highperformance liquid chromatography. Int J Syst Bacteriol 39, 159-167.

Minnikin, D. E. \& Minnikin, M. (1981). Lipids in the classification of Bacillus and related taxa. In The Aerobic Endospore-Forming Bacteria (Special Publications of the Society for General Microbiology no. 4), pp. 59-90. Edited by R. C. W. Berkeley \& M. Goodfellow. London: Academic Press.

Miroshnichenko, M. L., Kostrikina, N. A., L'Haridon, S., Jeanthon, C., Hippe, H., Stackebrandt, E. \& Bonch-Osmolovskaya, E. A. (2002). Nautilia lithotrophica gen. nov., sp. nov., a thermophilic sulphurreducing $\varepsilon$-proteobacterium isolated from a deep-sea hydrothermal vent. Int J Syst Evol Microbiol 52, 1299-1304.

Miroshnichenko, M. L., L'Haridon, S., Schumann, P., Spring, S., Bonch-Osmolovskaya, E. A., Jeanthon, C. \& Stackebrandt, E. (2004). Caminibacter profundus sp. nov., a novel thermophile of Nautiliales ord. nov. within the class 'Epsilonproteobacteria', isolated from a deep-sea hydrothermal vent. Int J Syst Evol Microbiol 54, $41-45$.

Murray, R. G. E., Doetsch, R. N. \& Robinow, C. F. (1994). Determinative and cytological light microscopy. In Methods for General and Molecular Bacteriology, pp. 21-41. Edited by P. Gerhardt, R. G. E. Murray, W. A. Wood \& N. R. Krieg. Washington, DC: American Society for Microbiology.

Nazina, T. N., Tourova, T. P., Poltaraus, A. B. \& 8 other authors (2001). Taxonomic study of aerobic thermophilic bacilli: descriptions of Geobacillus subterraneus gen. nov., sp. nov. and Geobacillus uzenensis sp. nov. from petroleum reservoirs and transfer of Bacillus stearothermophilus, Bacillus thermocatenulatus, Bacillus thermoleovorans, Bacillus kaustophilus, Bacillus thermoglucosidasius and Bacillus thermodenitrificans to Geobacillus as the new combinations G. stearothermophilus, G. thermocatenulatus, G. thermoleovorans, G. kaustophilus, G. thermoglucosidasius and G. thermodenitrificans. Int J Syst Evol Microbiol 51, 433-446.
Nercessian, O., Fouquet, Y., Pierre, C., Prieur, D. \& Jeanthon, C. (2005). Diversity of Bacteria and Archaea associated with a carbonate-rich metalliferous sediment sample from the Rainbow vent field on the Mid-Atlantic Ridge. Environ Microbiol 7, 698-714.

Nystrand, R. (1984). Saccharococcus thermophilus gen. nov., sp. nov., isolated from beet sugar extraction. Syst Appl Microbiol 5, 204-219.

O'Leary, W. M. \& Wilkinson, S. G. (1988). Gram-positive bacteria. In Microbial Lipids, pp. 117-201. Edited by C. Ratledge \& S. G. Wilkinson. London: Academic Press.

Pikuta, E., Lysenko, A., Chuvilskaya, N., Mendrock, U., Hippe, H., Suzina, N., Nikitin, D., Osipov, G. \& Laurinavichius, K. (2000). Anoxybacillus pushchinensis gen. nov., sp. nov., a novel anaerobic alkaliphilic, moderately thermophilic bacterium from manure, and description of Anoxybacillus flavithermus comb. nov. Int J Syst Evol Microbiol 50, 2109-2117.

Rainey, F. A., Ward-Rainey, N., Kroppenstedt, R. M. \& Stackebrandt, E. (1996). The genus Nocardiopsis represents a phylogenetically coherent taxon and a distinct actinomycete lineage: proposal of Nocardiopsaceae fam. nov. Int J Syst Bacteriol 46, 1088-1092.

Rhuland, L. E., Work, E., Denman, R. F. \& Hoare, D. S. (1955). The behaviour of the isomers of $\alpha, \varepsilon$-diaminopimelic acid on paper chromatograms. J Am Chem Soc 77, 4844-4846.

Santini, J. M., Streimann, I. C. A. \& vanden Hoven, R. N. (2004). Bacillus macyae sp. nov., an arsenate-respiring bacterium isolated from an Australian gold mine. Int J Syst Evol Microbiol 54, 2241-2244.

Schleifer, K. H. \& Kandler, O. (1972). Peptidoglycan types of bacterial cell walls and their taxonomic implications. Bacteriol Rev 36, 407-477.

Slobodkin, A. I., Tourova, T. P., Kuznetsov, B. B., Kostrikina, N. A., Chernyh, N. A. \& Bonch-Osmolovskaya, E. A. (1999). Thermoanaerobacter siderophilus sp. nov., a novel dissimilatory Fe(III)-reducing anaerobic thermophilic bacterium. Int J Syst Bacteriol 49, 1471-1478.

Slobodkin, A. I., Tourova, T. P., Kostrikina, N. A., Chernyh, N. A., Bonch-Osmolovskaya, E. A., Jeanthon, C. \& Jones, B. E. (2003). Tepidibacter thalassicus gen. nov., sp. nov., a novel moderately thermophilic, anaerobic, fermentative bacterium from a deep-sea hydrothermal vent. Int J Syst Evol Microbiol 53, 1131-1134.

Sokolova, T. G., Gonzalez, J. M., Kostrikina, N. A., Chernyh, N. A., Tourova, T. P., Kato, C., Bonch-Osmolovskaya, E. A. \& Robb, F. T. (2001). Carboxydobrachium pacificum gen. nov., sp. nov., a new anaerobic, thermophilic, CO-utilizing marine bacterium from Okinawa Trough. Int J Syst Evol Microbiol 51, 141-149.

Spring, S., Wagner, M., Schumann, P. \& Kämpfer, P. (2005). Malikia granosa gen. nov., sp. nov., a novel polyhydroxyalkonateand polyphosphate-accumulating bacterium isolated from activated sludge and reclassification of Pseudomonas spinosa as Malikia spinosa comb. nov. Int J Syst Evol Microbiol 55, 621-629.

Switzer Blum, J., Burns Bindi, A., Buzzelli, J., Stolz, J. F. \& Oremland, R. S. (1998). Bacillus arsenicoselenatis, sp. nov., and Bacillus selenitireducens, sp. nov.: two haloalkaliphiles from Mono Lake, California that respire oxyanions of selenium and arsenic. Arch Microbiol 171, 19-30.

Takai, K., Inagaki, F., Nakagawa, S., Hirayama, H., Nunoura, T., Sako, Y., Nealson, K. H. \& Horikoshi, K. (2003). Isolation and phylogenetic diversity of members of previously uncultivated epsilon-Proteobacteria in deep-sea hydrothermal fields. FEMS Microbiol Lett 218, 167-174.

Tamaoka, J. \& Komagata, K. (1984). Determination of DNA base composition by reversed-phase high-performance liquid chromatography. FEMS Microbiol Lett 25, 125-128.

Tindall, B. J. (1990a). A comparative study of the lipid composition of Halobacterium saccharovorum from various sources. Syst Appl Microbiol 13, 128-130. 
Tindall, B. J. (1990b). Lipid composition of Halobacterium lacusprofundi. FEMS Microbiol Lett 66, 199-202.

Urios, L., Cueff, V., Pignet, P. \& Barbier, G. (2004). Tepidibacter formicigenes sp. nov., a novel spore-forming bacterium isolated from a Mid-Atlantic Ridge hydrothermal vent. Int J Syst Evol Microbiol 54, 439-443.
Wery, N., Moricet, J.-M., Cueff, V., Jean, J., Pignet, P., Lesongeur, F., Cambon-Bonavita, M.-A. \& Barbier, G. (2001). Caloranaerobacter azorensis gen. nov., sp. nov., an anaerobic thermophilic bacterium isolated from a deep-sea hydrothermal vent. Int JSyst Evol Microbiol51, 1789-1796.

Wolin, E. A., Wolin, M. J. \& Wolfe, R. S. (1963). Formation of methane by bacterial extracts. J Biol Chem 238, 2882-2888. 